\title{
KUALITAS HIDUP LANSIA DENGAN HIPERTENSI DI WILAYAH KERJA PUSKESMAS SEGERI KABUPATEN PANGKEP
}

\author{
Rahmawati Ramli ${ }^{1)}$ Najihah $^{2)}$ \\ ${ }^{1}$ Fakultas Kesehatan Masyarakat, Universitas, Muslim Indonesia \\ email: rahmawati.ramli@umi.ac.id \\ ${ }^{2}$ Fakultas Kesehatan Masyarakat, Universitas, Muslim Indonesia \\ email: jia.najihah@yahoo.co.id
}

\begin{abstract}
Globally in 2012, of all deaths, non-communicable diseases caused $68 \%$ deaths and the majority of premature deaths $(82 \%)$ because non-communicable diseases occurred in countries with low and middle opinions. And of all non-communicable disease-related deaths, $46 \%$ came from cardiovascular disease . Long-term hypertension can cause a decline in cognitive function, which of course will greatly disrupt the quality of life of patients.

The aim of the study was to determine the quality of life of elderly people with hypertension in the Work Area of Segeri Health Center, Pangkep Regency. This research method uses qualitative research with a focus on phenomenological approaches. The research instrument is the researcher himself. Determination of samples using purposive sampling technique.

The results of this study found the quality of life of the elderly in terms of the physical aspects of the elderly experiencing physical problems that disrupt activities, psychological aspects that consider the disease to be acquired due to the aging process, social aspects namely the elderly have good social relations with neighbors, and environmental aspects that are comfortable and safe.

It is expected to provide clear and complete information to elderly hypertensive patients and families about the care of elderly hypertension and how to treat hypertension.l
\end{abstract}

Keywords: Elderly, Quality of life, hipertension. 


\section{PENDAHULUAN}

Secara global pada tahun 2012, dari semua kematian, penyakit tidak menular menyebabkan kematian $68 \%$ dan mayoritas prematur kematian (82\%) karena penyakit tidak menular terjadi pada negara negara dengan pendapat rendah dan menengah. Dan dari semua kematian terkait penyakit tidak menular, $46 \%$ berasal dari kardiovaskular penyakit (WHO, 2014). Salah satu penyakit kardiovaskur yang paling banyak terjadi adalah hipertensi.

Hipertensi merupakan peningkatan tekanan darah sistolik lebih dari $140 \mathrm{mmhg}$ dan tekanan darah diastolic lebih dari $90 \mathrm{mmHg}$ pada dua kali pengukuran selang waktu lima menit dalam keadaancukup tenang/ istirahat (Kemenkes RI, 2013). Penyakit hipertensi biasa disebut slient killer karena termasuk mematikan tanpa adanya gejalagejala terlebih dahulu sebagai peringatan. Biasanya gejala-gejalanya seperti sakit kepala, rasa berat ditengkuk, vertigo, jantung berdebar, mudah lelah dan penglihatan kabur (Kemenkes, 2013).

Penduduk Amerika yang berusia diatas 20 tahun menderita hipertensi telah mencapai angka 74,5 juta jiwa (AHA, 2014). Angka kejadian hipertensi di dunia yang menduduki peringkat tertinggi adalah di Afrika sebesar 46\%, kawasan Asia Tenggara $36 \%$ orang dewasa menderita hipertensi. Kejadian hipertensi di Asia Tenggara telah membunuh 1,5 juta jiwa dan sepertiga populasi orang dewasa hidup dengan hipertensi (WHO, 2011). Diprediksikan pada tahun 2025 angka kejadian hipertensi akan meningkat sekitar $29 \%$ atau sekitar 1,6 miliar orang dewasa di seluruh dunia (Kemenkes RI, 2013).

Berdasarkan riskesdas tahun 2013, penyakit terbanyak adalah hipertensi $(56,7 \%$, artritis $(51,9 \%)$ dan stroke $(46,1 \%)$ dan masih ada (28\%) lansia mempunyai lebih dari satu penyakit ( Riskesdas, 2013). Penyakit terbanyak pada lansia adalah hipertensi dengan prevalensi $45,9 \%$ pada usia $55-64$ tahun, $57,6 \%$ pada usia $65,74 \%$ dan $63,8 \%$ pada usia> 75 tahun (Infodatin Kemenkes RI, 2016).

Hipertensi jangka lama dapat menyebabkan penurunan fungsi kognitif, yang tentunya akan sangat menganggu kualitas hidup penderita. (Elias, Goodell, \& Dore, 2012). Penelitian yang dilakukan oleh Kaliyaperumal, dkk (2016) di India mendapatkan hasil bahwa hipertensi menganggu kuaitas hidup lansia baik secara fisik maupun mental.

Hasil penelitian tentang kualitas hidup pasien hipertensi di Katmandhu Nepal menunjukkan bahwa peningkatan usia, pendidikan non formal, lajang memiliki kualitas hidup yang rendah (Bhandari, Ram, Takma, \& Lawot, 2016).

Pada laporan rekapitulasi 10 penyakit terbesar triwulan satu dan triwulan dua tahun 2014 Dinas Kesehatan Kabupaten Pangkep, penyakit hipertensi menempati urutan ke empat dengan total kasus sebanyak 6.262 kasus pada triwulan satu dan 5.358 kasus pada triwulan dua. (Dinkes Kab. Pangkep 2014)

Berdasarkan hasil wawancara 5 lansia yang mengalami hipertensi di wilayah kerja Puskesmas Segeri Kabupaten pangkep, para lansia menyatakan jika telah banyak perubahan yang diarasakan terjadi. Salah satunya adalah gampang marah, cepat tersinggung dan gampang panik. Lansia mengatakan tidak mampu lagi melakukan beberapa aktifitas fisik seperti dulu lagi. Lansia pun mulai membatasi pola makan serta kebiasaan-kebiasaan hidup karena mulai ketergantungan obat. Oleh karena hal tersebut peneliti tertarik meneliti tentang kualitas hidup lansia di Segeri.

\section{METODE}

Jenis penelitian yang digunakan dalam penelitian ini adalah metode penelitian kualitatif dengan desain fenomenologi. Penelitian ini dilaksanakan di wilayah kerja puskesmas segeri kabupaten pangkep. Waktu penelitian akan dilaksanakan pada September - Maret 2019. Jumlah responden adalah 12 orang. Pengumpulan data dilakukan dengan tehnik wawancara dan observasi yang hasilnya disajikan dalam bentuk narasi.

\section{HASIL DAN PEMBAHASAN Hasil Penelitian}

a. Kondisi Fisik 
Hasil wawancara mendalam didapatkan bahwa hampir semua informan mengalami masalah fisik seperti sakit kepala, sakit pinggang, sakit tengkuk pusing atau sakit seluruh badan tapi mereka cukup merasa terganggu dalam beraktifitas. Seperti yang diungkapkan informan berikut.

"...Masekkang usedding mapeddi cekkongku na mataku masekkang lala' lala' dema stiap hari. Akko sedding mepeddisi makkedaka awe magasiro. Monro sikka tudang. pakkuniro tauwe akko matoani maegani lasa pole tapi dema najujai eddangka'..." ( NM, 65 tahun, Lansia)".

“...Uluukku aga napoji mapeddi sibawa malippuno na matojo cekkongku. Biasa akko mannasuka tappa maliipunoka. Tapi taccinami Sangi manreku pabbura tekanan darah tinggi eloni cappu sipapeng, apa akko de' uanre de ullei majjama jama nataro..." (SR, 70 Tahun, Lansia)

Hal yang sama pun diungkapkan oleh keluarga informan terhadap masalah yang dihadapi oleh Lansia yang kadang cukup menggganggu aktifitas sehari- hari bahkan sampai pingsan. Seperti yang diungkapkan informan berikut.

“...Sejak hipertensi terus Sering sekali tegang lehernya. Ndak tentu kadang pagi kadang siang. Malah pernah pingsan karna mauki kerumah liat cucunya tiba2 pusingki dijalan..."(Informan M, 45 Tahun)

“...Kalau misalnya ada dia kerja seringki tiba-tiba pusing. Kayak memasak, menyapu. Mungkin pengaruh karna memang lamami begini tekanan darahnya, dari dulu memang selalu tinggi..." ( Informan L, 45 Tahun)

Hal ini juga sesuai yang dikatakan oleh petugas puskesmas. Petugas puskesmas dalam hal ini penanggung jawab program kesehatan lansia mengatakan bahwa biasanya lansia yang mengalami hipertensi akan mengalami gangguan kesehatan fisik rasa pegal atau tidak nyaman ditengkuk, sakit kepala, pusing, dan jantung berdebar debar. Dan biasanya pasti cukup menganggu aktifitas sehari hari para lansia. Seperti yang diungkapkan infroman berikut.

“...Sebagian besar lansia yang hipertensi baik yang baru mengalami maupun yang telah bertahun tahun pasti akan mengalami keluhan seperti sakit kepala, pusing, sakit pada tengkuk, dan jantung berdebar-debar. Dengan gejala demikian tentunya akan cukup menganggu aktifitas harian lansia. Ada beberapa kasus lansia masuk Puskesmas karna pusing atau sakit kepala tak tertahankan..."(HSN, 27 tahun, Petugas Puskesmas)

\section{b. Kondisi Psikologis}

Hasil wawancara didapatkan sebagian besar informan semua mengatakan cukup menikmati hidup dan merasa puas dengan hidupnya dan merasa tidak perlu memikirkan penyakit yang diderita karna menganggap itu disebabkan karna faktor penuaan. Seperti yang di ungkapkan informan berikut.

"...Unikmatima, dema upikiri peddiku, dema upikiri i. makku metto tauwe akkomatoani, maegani lasa. Dena napada biasae. akko engkasi mapeeddi peddi minum sikki pabbura, makku tommiro matu napaja ..."( Informan NM, 65 Tahun)

Cukup menikmati hidup dengan tetap makan makanan yang disukai dan masih mendapat kunjungan dari anak dan cucu. Seperti yang diungkapkan informan berikut.

“...Bah. Manyamengma usedding nyawaku. Apa iya uanre manengma pantanganna lasae...(ketawa). Namu matanre tekanan darahku manre tomma doang sibawa bukkang. Nappa nakko sabtu engkammi lao mai anakku. Tette tiap sabtu sibawa appoku aga. Marennu ka ro seeding apa namu mabelai engkammi lao mai..." ( Informan KMR, 86 Tahun)

“...Bah puasma sedding, apa iya engka matteru ma obatku. Jadi akko engkamma obatku dema umatau" namu aleleku... "(Informan SD, 61 Tahun)

Hal ini sesuai yang diungkapkan keluarga. Seperti yang diungkapkan informan berikut.

“...Untungnya saya itu dekat dekat sinija tinggal, semenjak meninggal mamaku saya mami uruski kodong. Jadi kalau pagi- pagi pokoknya sudahma masaka kubawakanmi makanan. Kubawa mi juga anakku main dirumah nya supaya tidak kesepianki..." (Informan ML, 45 Tahun) 
Namun berbeda dialami oleh beberapa informan yang mengatakan kurang menikmati hidupnya dikarenakan sering merasa terganggu akibat hipertensinya ataupun karna masalah lain.

Ada beberapa hal yang menyebabkan lansia hipertensi tidak menikmati hidupnya yaitu karna penyakitnya sehingga merasa tidak mampu lagi seperti biasanya. Seperti yang diungkapkan informan berikut ini.

“...Yammiro sedding biasa upikiri akko menre toni tensikku denakasi ullei majama jama mareso. Na detona gagaga passappa'ta. Ubaling manni sideppe bolae mabalu-balu. $\mathrm{Na}$ engka tosi kasi anakku dena normal. Biasaka kasi nacalla dewissengi magai..." (Informan KMR, 86 Tahun)

Hal lain diungkapkan keluarga jika informan kehilangan suaminya 2 bulan yang lalu dan pernah dirampok dan diikat dirumahnya semenjak suaminya hidup. Setelah suaminya meninggal informan merasa tidak tenang tinggal dirumah sendiri. Seperti yang diungkapkan informan berikut ini.

“...Baru baru meninggal suaminya, sekitar 2 bulan lalu. Semenjak meninggal suaminya tidak mauki menginap dirumahnya sendiri karna takutki. Pernah dulu waktu hidup suaminya dirampokki baru diikat. Jadi itumi kapang natakut-takut..." (Informan HS, 27 Tahun)

Hal yang tidak jauh berbeda diungkapkan oleh Petugas Puskesmas yang mengatakan bahwa lansia yang hipertensi cukup menikmati hidupnya dan menganggap hipertensi ini sebagai penyakit akibat penuaan. Justru masalah lain seperti keuangan, hidup sendiri atau bahkan berjauhan dari anak yang menjadikan lansia merasa tidak nyaman. Seperti yang diungkapkan Petugas Puskesmas berikut.

"...Kalau secara psikologis saya kira tidak terlalu ada yang berubah. Mereka saya lihat tidak terlau memikirkan atau menjadikan beban hidup terhadap masalah kondisi fisiknya. Mereka menganggap ini hal wajar, yah karna sudah tua makanya hipertensi, justru terkadang masalah yang seperti masalah keuangan, kehilangan pasangan atau bahkan jauh dari keluarga dan anaklah yang menjadi beban pemikiran mereka. Maklum rata-rata sudah ditinggal menikah oleh anaknya. ..." (HSN, 27 Tahun, Petugas Puskesmas)

c. Hubungan Sosial
Sebagian besar informan mengatakan tidak ada masalah dengan hubungan sosialnya baik terhadap keluarga maupun terhadap tetangga. Hal ini ditandai dengan silaturahmi yang terus terjalin dengan tetangga setiap hari. Hal ini seperti yang diungkapkan infroman berikut.

“...Esso esso ma lao jokka kusedde bolae. Akko tannia ele aruweng. Dema sedding bombe bombeku. Dena wissengi akko idi naseng meja'sipa. Keluarga laine biasa ma aga sitelpon akko dewullei lao bolana... "(Informan SR, 70 Tahun).

“...Nakko sabtu engkammi lao maia anakku. Tette tiap sabtu sibawa cucuku aga. Marennu ka ro seeding apa namu mabelai engkammi lao mai..." (KMR, 86 Tahun, Lansia)

d. Lingkungan

Sebagian besar informan berpendapat bahwa merasa aman tinggal di lingkungan yang di tinggali saat ini. Seperti yang diungkapkan informan berikut ini.

“...Aman mua usedding monro kue. Selama ini demagaga masalah. Detomma utau' taureng sedding. upoji ma..." (Informan NM, 65

\section{Tahun)}

“...Amanma sedding, demagaga masalah, biasa akko aruwengngi lao sikka masepada sepeda. Makanja ma sedding, maittana mondro kuhe toh. Mappulo kapang..." (Informan KMR, 86 Tahun)

Berdasarkan Petugas Puskesmas mengatakan bahwa kondisi lingkungan lansia cenderung aman dan baik sehingga membuat lansia pun merasa tenang dan bahkan membuat kuaitas hidup lansia menjadi cukup baik ditinjau dari aspek lingkungan.

“...Jika dari aspek lingkungan nya, saya kira lingkungan yang mereka tempati sekarang adalah lingkungan yang cukup aman, karena mereka rata-rata tinggal di lingkungan tersebut sudah cukup lama..."(HSN, 27 Tahun, Petugas Puskesmas)

\section{Pembahasan}

\section{a. Kondisi Fisik}

Pada lansia, hipetensi didefinisikan sebagai tekanan sistolik kurang lebih $160 \mathrm{mmHg}$ dan tekanan diastolik kurang lebih $90 \mathrm{mmHg}$. (Brunner \& Sudarth, 2001 dalam Yuli. 2014). Berdasarkan hasil penelitian didapatkan bahwa sebagian besar Lansia memiliki masalah kesehatan pada kondisi fisiknya seperti sakit kepala, sakit tengkuk, pusing. Kondisi tersebut 
cukup mengganggu beberapa aktifitas sehari hari lansia seperti jika saat beraktifitas harus berhenti sejenak.

Hal ini sejalan dengan penelitian oleh Anbarasan (2015). Pada penelitian ini, ditinjau dari dimensi kesehatan fisik, lansia dengan hipertensi ditemukan kualitas hidup yang buruk sebesar $71.7 \%$ bahwa terdapat hubungan antara hipertensi dengan kualitas hidup yang rendah, terutama pada dimensi fisik dan psikologis.

Menurut peneliti kondisi fisik yang memiliki masalah tentunya kan berpengaruh baik sedikit maupun banyak terhadap aktifitas sehari-hari lansia. Selain kondisi fisik yang bermasalah tentunya tidak bisa lepas faktor proses penuaan yang juga membuat lansia tidak mampu untuk beraktifitas seperti biasanya.

\section{b. Psikologis}

Kualitas hidup ditinjau dari aspek psikologis berdasarkan hasil penelitian didapatkan hampir keseluruhan Lansia memiliki kualitas hidup yang baik. Hipertensi yang menyebabkan beberapa gangguan pada kondisi fisik ternyata dianggap hal yang wajar oleh lansia. Mereka beranggapan penyakit itu disebabkan karna faktor usia.

Hal ini terjadi karena rata-rata lansia dalam penelitian ini tidak memiliki perasaan kesepian, putus asa dan cemas. Hal ini disebabkan karena rata-rata lansia masih tinggal bersama anakanak, cucu, dan menantunya. Lansia yang kurang dukungan keluarga, dimana anggota keluarga sibuk dengan urusan masing-masing, hal ini menyebabkan lansia merasa tertekan akibat menyendiri sehingga harapan hidupnya kurang baik, dan mempengaruhi kualitas hidupnya menjadi tidak baik (Kartininggrum, 2017).

Menurut peneliti, kualitas hidup lansia ditinjau dari aspek psikogisnya yaitu lansia menganggap penyakit yang diperoleh karna faktor usia, dan merupakan hal yang wajar. Beberapa faktor menyebabkan kualitas hidup baik adalah keberadaan keluarganya yang berada di dekat nya yang membuat nya tetap merasa tenang dan nyaman.

\section{c. Hubungan Sosial}

Hubungan sosial yang dimaksud adalah hubungan para lansia dengan tetangga, keluarga bahkan teman teman lansia. Hasil penelitian didapatkan bahwa kualitas hidup lansia ditinjau dari aspek hubungan sosial cukup. Semua informan mengatakan tetap memiliki hubungan sosia yang baik dengan keluarga bahkan tetangganya. Hal ini ditandai dari terjainnya komunikasi yang rutin setiap hari terhadap keluarga dan tetangga. Contohnya mereka sering mengunjungi rumah keluarga atau tetangga hampir setiap hari entah itu pagi atau sore hari.

Hal ini pun sejalan dengan penelitian yang mengatakan bahwa individu yang membatasi hubungan sosianya dengan lingkungan sekitar berpeluang untuk merasa kesepian yang berarti kualitas hidupnya akan kurang baik. (Sanjaya, 2012)

Selain itu dengan adanya dukungan sosial yang diberikan oleh teman sebaya akan memotivasi lansia untuk lebih baik dalam melakukan aktivitas sehari-hari maupun masalah yang dihadapinya (Azwan, 2015).

Menurut peneliti kuaitas hidup yang baik dari aspek hubungan sosial karna para lansia masih menjaga komunikasi yang baik dari keluarga, teman dan tetangga. Mereka pun masih selalu berinteraksi setiap hari dan bersilaturahmi dengan tetangga terdekat. Hal ini menyebabkan hubungan sosia yang baik tetap bertahan.

\section{d. Lingkungan}

Berdasarkan hasil penelitian didapatkan bahwa lansia mengatakan bahwa merasa nyaman dan aman tinggal dilingkungan yang sekarang ditempati dan merasa tidak ada hal- hal yang perlu ditakutkan. Yang menjadi kekhawatiran terkadang hanya jika terjadi banjir yang datang disaat musim penghujan tiba.

Lansia yang telah lama mendiami suatu wilayah merasa cukup aman dan tidak ada hal- hal yang perlu dipikirkan terkait lingkungan. Hal ini tidak sejalan penelitian yang dilakukan terhadap kualitas hidup lansia yang hipertensi didapatkan kualitas lingkungan buruk sebesar $73.3 \%$. (Anbarasan, 2015)

Menurut peneliti kualitas hidup lansia dari aspek lingkungan cukup baik karena semua lansia merasa aman tinggal ditempat tinggalnya yang sekarang. Hal ini dikarenakan mereka telah lama tinggal di lingkungan saat ini. Dan sudah sangat tahu kondisi lingkungan yang mereka tinggali. Lingkungan yang mereka tinggali pun cenderung merupakan lingkungan yang sehat.

\section{KESIMPULAN}

1. Kualitas hidup lansia ditinjau dari aspek kondisi fisik yaitu 
a. Lansia Hipertensi mengalami masalah fisik seperti pusing, sakit pada tengkuk, sakit pinggang dan sakit seluruh badan

b. Kondisi fisik yang bermasalah mengakibatkan terganggunya aktifitas sehari-hari.

2. Kualitas hidup lansia ditinjau dari aspek psikologis didapatkan

a. Tidak memikirkan penyakitnya dan menganggap penyakit adalah faktor penuaan

b. Lansia hipertensi merasa aman dan nyaman dalam keadaan apapun jika lansia hipertensi berada dekat dengan keluarga seperti anak dan cucu.

c. Memikirkan diri yang tidak mampu lagi beraktifitas seperti biasanya.

d. Lansia hipertensi memiliki masalah pribadi seperti sudah tidak memiliki pasangan, kekurangan keuangan, jauh dari keluarga.

3. Kualitas hidup lansia ditinjau dari hubungan sosial yaitu lansia tetap menjalin hubungan yang baik dengan tetangga, keluarga dan sesama lansia.

4. Kualitas hidup lansia ditinjau dari aspek lingkungan yaitu

a. lansia merasa aman dan nyaman tinggal dil ingkungan tempat tinggal yang sekarang

b. Lingkungan yang ditempati merupakan lingkungan yang telah lama dihuni dan cenderung merupakan lingkungan yang sehat

\section{REFERENSI}

1. Anbarasan SS. 2015. Gambaran Kualitas Hidup Lansia dengan Hipertensi di Wilayah Kerja Puskesmas Rendang pada Periode 27 Februari-14 Maret 2015. Jurnal Kedokteran. Vol 4 (1): 113-124.

2. Azwan, Herlina, \& Karim, D. (2015). Hubungan dukungan sosial teman sebaya dengan kualitas hidup lansia dipanti sosial tresna werdha. http://jom.unri.ac.id/index.php/JOMPSI K/article/view/8258/7929.

3. Bhandari, N., Ram, B., Takma, K. C., \& Lawot, I. (2016). International Journal of Nursing Sciences Quality of life of patient with hypertension in Kathmandu. International Journal of Nursing Sciences, 3(4), 379-384. https://doi.org/10.1016/j.ijnss.2016.10.002

4. Dinkes Kabupaten Pangkep.(2014). Laporan SP2TP Dinas Kesehatan Kabupaten Pangkep. Pangkep : Dinas Kesehatan Kabupaten Pangkep.

5. Dewi, p. r., \& sudhana, i. w. (2013). Puskesmas gianyar $i$ periode bulan november tahun 2013 quality of life in elderly with normotension or hypertension in puskesmas gianyar 1 area of work during november 2013, 1-14.

6. Elias, M. F., Goodell, A. L., \& Dore, G. A. (2012). Hypertension and Cognitive Functioning A Perspective in Historical Context, 260-268. https://doi.org/10.1161/HYPERTENSION AHA.111.186429

7. Kaliyaperumal S, Hari S, Siddela K, dkk. 2016. Assessment of Quality of Life in Hypertensive Patients. Journal of Applied Pharmaceutical Science. Vol 6 (5) :143147 May 2016. India : Department of Pharmacy Practice, JKK.

8. Sanjaya, A., Rusdi, I (2012). Hubungan Interaksi Sosial Dengan Kesepian Pada Lansia. Naskah Publikasi, Universitas Sumatera Utara.

9. Sari N. (2013). Status Gizi, Penyakit Kronis, dan Konsumsi Obat terhadap Kualitas Hidup Dimensi Kesehatan Fisik Lansia. Skripsi Naskah Publikasi. (Online).

10.WHO. (2014). Global status report on noncommunicable diseases. World Health; 2014. p. 176. ISBN 9789241564854.।

11.Yuli, RA. (2014). Buku Ajar Asuhan Keperawatan Gerontik. Jakarta : Trans Info Media.

12.Zhang Y, Zhou Z, Gao J, dkk. (2016). Healthrelated quality of life and its influencing factors for patients with hypertension: evidence from the urban and rural areas of Shaanxi Province, China. (Online) 